\title{
Soil Vulnerability Index assessment as a tool to explain annual constituent loads in a nested watershed
}

\author{
S. Lohani, C. Baffaut, A.L. Thompson, and E.J. Sadler
}

\begin{abstract}
The SoilVulnerability Index (SVI) was developed by the USDA Natural Resources Conservation Service (NRCS) to identify inherent vulnerability of cropland to runoff and leaching. It is a simple index that relies on the SSURGO database and can be used with basic knowledge of ArcGIS. The goal of this study was to investigate a relationship between constituent (sediment and nutrient) loadings and fraction of the watershed in each SVI class. The SVI maps were developed for each of the seven subwatersheds of the Mark Twain Lake watershed in Missouri, which were similar in soil conditions and climatic variability. The SVI assessment was performed by investigating if the distribution of the SVI for cropland in each subwatershed could help explain measured 2006 to 2010 sediment and nutrient loads better than crop distribution alone. Regression analyses were performed between annual loads of sediment and nutrients exported from the watersheds and a composite number that included either cropland distribution alone, or cropland distribution combined with the SVI. Coefficients of determination and $p$-values were compared to assess the ability of land use and SVI distributions to explain stream loads. Integrating the SVI in the land cover variable improved the ability to explain constituent loads in the watersheds for sediment, total nutrients, and dissolved nitrogen $(\mathrm{N})$. Regression results with and without the SVI were identical for dissolved phosphorus $(\mathrm{P})$, potentially indicating that SVI was not indicative of dissolved $\mathrm{P}$ transport at the current site. Overall, the application of the SVI at watershed scale was not perfect, but acceptable at correctly identifying cropland of greatest vulnerability and linking with transported constituent loads.
\end{abstract}

Key words: nutrient load—sediment load—soil vulnerability index-SVI

The Soil Vulnerability Index (SVI) is a simple index proposed by the USDA Natural Resources Conservation Service (USDA NRCS) to identify areas that are inherently vulnerable to runoff-induced sediment and nutrient loss, and to leaching-induced loss of nutrients in percolation and subsurface flows. The NRCS developed the SVI as part of the Conservation Effects Assessment Project (CEAP) cropland study (USDA NRCS 2012) to rank cropland soils in the United States based on their inherent vulnerability to surface runoff and leaching. The SVI has two components: the soil runoff component and the soil leaching component. The soil runoff potential is determined based on the hydrologic soil group, slope, and soil erodibility $\mathrm{K}$-factor; the same properties along with organic matter content and rock
The SVI is intended for use at the field level for assessing the soil vulnerability when defining a conservation plan. It can also be applied for all the fields in a watershed or a region in order to define regional conservation needs and prioritize efforts and funds. Validation of field-level indices, such as the Phosphorus Index (PI), can be done using edge-of-field monitoring data (Butler et al. 2010; Eghball and Gilly 2001; Harmel et al. 2005). However, the SVI is not conducive to this type of evaluation because the SVI provides a categorical ranking (low to high) of the inherent risk of growing crops on the field, not an estimate of sediment or nutrient loss, which also reflect management and weather. While a specific experiment could be designed to experimentally assess the validity of the SVI using monitoring data, this was beyond the scope of this study.

Another approach used to evaluate the ability of field indices to assess where sediment and nutrient losses are more likely to occur is to compare the field indices to the results from watershed-scale simulation models. Veith et al. (2005) used this type of approach to evaluate a proposed PI, and Chan et al. (2017), Yasarer et al. (2020), and Lee et al. (2018) used it to assess the SVI. Chan et al. (2017) evaluated the SVI in the fairly homogeneous claypan Goodwater Creek Experimental Watershed and concluded that the SVI would benefit from using a digital elevation model (DEM) derived slope instead of using the SSUR GO representative slope. Lee et al. (2018) compared the performance of the SVI in identifying areas at risk of losing nitrogen $(\mathrm{N})$ via surface runoff and nitrate $\left(\mathrm{NO}_{3}\right)$ via leaching against Soil and Water Assessment Tool (SWAT) (Arnold et al. 1998) model outputs on two adjacent subwatersheds in the Chesapeake Bay watershed. The study showed that SVI runoff risk classification corresponded to organic $\mathrm{N}$, and that SVI leaching risk classification corresponded more to $\mathrm{NO}_{3}$ leaching vulnerability. Yasarer and leaching: low, moderate, moderately high, and high, based on specific thresholds for the soil and landscape parameters listed above (tables 1 and 2). These parameters and thresholds were determined based on simulation results with the Agricultural Policy Environmental eXtender (APEX) model in the Upper Mississippi River, Ohio, and Tennessee River basins across a subset of National Resources Inventory (NRI) locations (Thompson et al. 2020).
Sapana Lohani is a postdoctoral scholar in the Department of Biology, University of NevadaReno, Reno, Nevada. Claire Baffaut is a research hydrologist at the Cropping Systems and Water Quality Research Unit, USDA Agricultural Research Service (ARS), Columbia, Missouri. Allen L. Thompson is a professor in the Department of Bioengineering, University of Missouri, Columbia, Missouri. E. John Sadler is research leader at the Cropping Systems and Water Quality Unit, USDA ARS, Columbia, Missouri. 
Table 1

Land cover classes in the Mark Twain Lake watershed.

\begin{tabular}{lc}
\hline Land cover classes & Land use types \\
\hline $\begin{array}{l}\text { Corn/sorghum } \\
\text { Soybean }\end{array}$ & Corn (Zea mays L.; all kinds), sorghum (Sorghum bicolor L.), and successions of two crops where one was corn or sorghum \\
Other annual crops & Soybeans (Glycine max [L.] Merr.) \\
& Sunflower (Helianthus annuus L.), winter wheat (Triticum aestivum L.), double crop winter wheat/soybeans, oats (Avena \\
& sativa L.), millet (Pennisetum glaucum [L.] R.Br.), other small grains, miscellaneous vegetables and fruits, rye (Secale \\
cereale L.), and rice (Oryza sativa L.) & Grass/pasture, other hay/nonalfalfa, switchgrass (Panicum virgatum L.), alfalfa (Medicago sativa L.), and clover \\
Grassland & (Trifolium)/wild flowers \\
Forest & Deciduous forest, evergreen forest, mixed forest, and woody wetlands \\
Other non-ag & wetlands, nonagricultural/undefined, perennial ice/snow, scrubland, water, and wetlands
\end{tabular}

\section{Table 2}

Criteria for the four classes of soil runoff potential (USDA NRCS 2016).

\begin{tabular}{|c|c|c|c|c|}
\hline \multirow{2}{*}{$\begin{array}{l}\text { Soil runoff } \\
\text { potential }\end{array}$} & \multicolumn{4}{|c|}{ Hydrologic soil group* } \\
\hline & $\mathbf{A}$ & B & C & D \\
\hline Low & All area & Slope $†<4$ & Slope $<2$ & $\begin{array}{l}\text { Slope }<2 ; \\
\text { K-factor } \neq<0.28\end{array}$ \\
\hline Moderate & None & $\begin{array}{l}4 \leq \text { slope } \leq 6 \\
\text { K-factor }<0.32\end{array}$ & $\begin{array}{l}2 \leq \text { slope } \leq 6 \\
\text { K-factor }<0.28\end{array}$ & $\begin{array}{l}\text { Slope }<2 \\
\text { K-factor } \geq 0.28\end{array}$ \\
\hline Moderately high & None & $\begin{array}{l}4 \leq \text { slope } \leq 6 \\
\text { K-factor } \geq 0.32\end{array}$ & $\begin{array}{l}2 \leq \text { slope } \leq 6 \\
\text { K-factor } \geq 0.28\end{array}$ & $2 \leq$ slope $\leq 4$ \\
\hline High & None & Slope $>6$ & Slope $>6$ & Slope $>4$ \\
\hline
\end{tabular}

*Hydrologic soil groups are classified as follows: Group A = sand, loamy sand, or sandy loam soils that have low runoff potential and high infiltration rates even when thoroughly wetted. Group $B=$ silt loam or loam soils that have moderate infiltration rates when thoroughly wetted. Group $\mathrm{C}=$ sandy clay loam soils that have low infiltration rates when thoroughly wetted. Group D = clay loam, silty clay loam, sandy clay, silty clay, or clay soils that have very low infiltration rates when thoroughly wetted.

†Slope values measured as percentage.

$\ddagger \mathrm{K}$-factor refers to the soil erodibility factor $(\mathrm{K})$ found in the Universal Soil Loss Equation. It is a relative index of susceptibility of bare, cultivated soil to particle detachment and transport by rainfall. It is determined by the composition of the soil, saturated hydraulic conductivity, and soil structure.

et al. (2020) compared SVI risk classification with Annualized Agricultural Non-Point Source (AnnAGNPS) (Bosch et al. 1998) model outputs in two watersheds in lower Mississippi. The study concluded that the SVI could identify potential areas that contribute to nonpoint source pollution, which could then be confirmed with field knowledge to decide where to place conservation practices. Overall these comparisons of rankings obtained with the SVI and with model results showed consistency between the two. However, they do not indicate that either one is correct. Thus, an assessment of SVI performance against monitoring data is needed.

One can use watershed-level monitoring data and index ratings in the watershed. Birr and Mulla (2001) used this technique to assess the validity of a modified PI at regional scale. The PI was modified to combine values from the different sites in a watershed according to land use and various other factors such as proximity to streams and fertilization rates. They concluded that the proposed PI could be used to prioritize efforts in a watershed to address areas of greater vulnerability.

The Mark Twain Lake (MTL) watershed in northeast Missouri offers a unique data set of nutrient and sediment loadings over five years (2006 to 2010) at the outlet of 10 subwatersheds. While these 10 watersheds were subjected to the same precipitation and temperature patterns and had soils predominantly in the same hydrologic soil group and with similar soil erodibility K-factors, the range and spatial distribution of slopes varied and resulted in different spatial distributions of vulnerability to runoff in the 10 watersheds. Thus, the MTL watershed readily lent itself to evaluating the impact of SVI distribution on annual constituent ( $\mathrm{N}$, phosphorus $[\mathrm{P}]$, and sediment) loads.

The goal of this study was to determine whether the spatial distribution of vulnera- bility to runoff and leaching can help explain constituent loads measured at each subwatershed outlet. Though the SVI was originally intended for field use, this paper used monitoring data at the subwatershed outlet points. The objectives of this study were to (1) develop maps of SVI risk classes for runoff and leaching in the MTL watershed in Missouri, and (2) investigate a relationship between constituent loadings and fraction of the watershed in each vulnerability class. Geospatial data layers were used to calculate the index and to analyze index values in the subwatersheds within the MTL watershed. A regression analysis was conducted between index spatial distribution across the watershed, land use distribution, and annual loads of constituents exported from the watersheds.

\section{Materials and Methods}

Study Area. The Salt River basin/MTL watershed is a CEAP USDA benchmark watershed (Lerch et al. 2008). It is situated in northeast Missouri and includes 10 subwatersheds (North Fork, Middle Fork, Elk Fork, Long Branch, South Fork, Lick Creek, Black Creek, Crooked Creek, Ely Creek, and Otter Creek) ranging in area from 271 to $1,579 \mathrm{~km}^{2}$ (figure 1). The Salt River basin drains $6,417 \mathrm{~km}^{2}$ at the outlet to the Mark Twain Lake. The basin is underlain by predominantly claypan soils, which have high runoff potential. Based on the availability of annual constituent loads, 7 out of 10 watersheds (all except Black Creek, Ely Creek, and Otter Creek) were considered in this study over a period of five years (2006 to 2010). Primary row crops in the area were soybean (Glycine max [L.] Merr.), corn (Zea mays L.), sorghum (Sorghum bicolor L.), and wheat (Triticum aestivum L.) (Lerch et al. 2008). Crop rotations in the MTL region included corn and soybean in equal proportions, cornsoybean-soybean, and continuous soybean 


\section{Figure 1}

Location map for the Salt River basin.

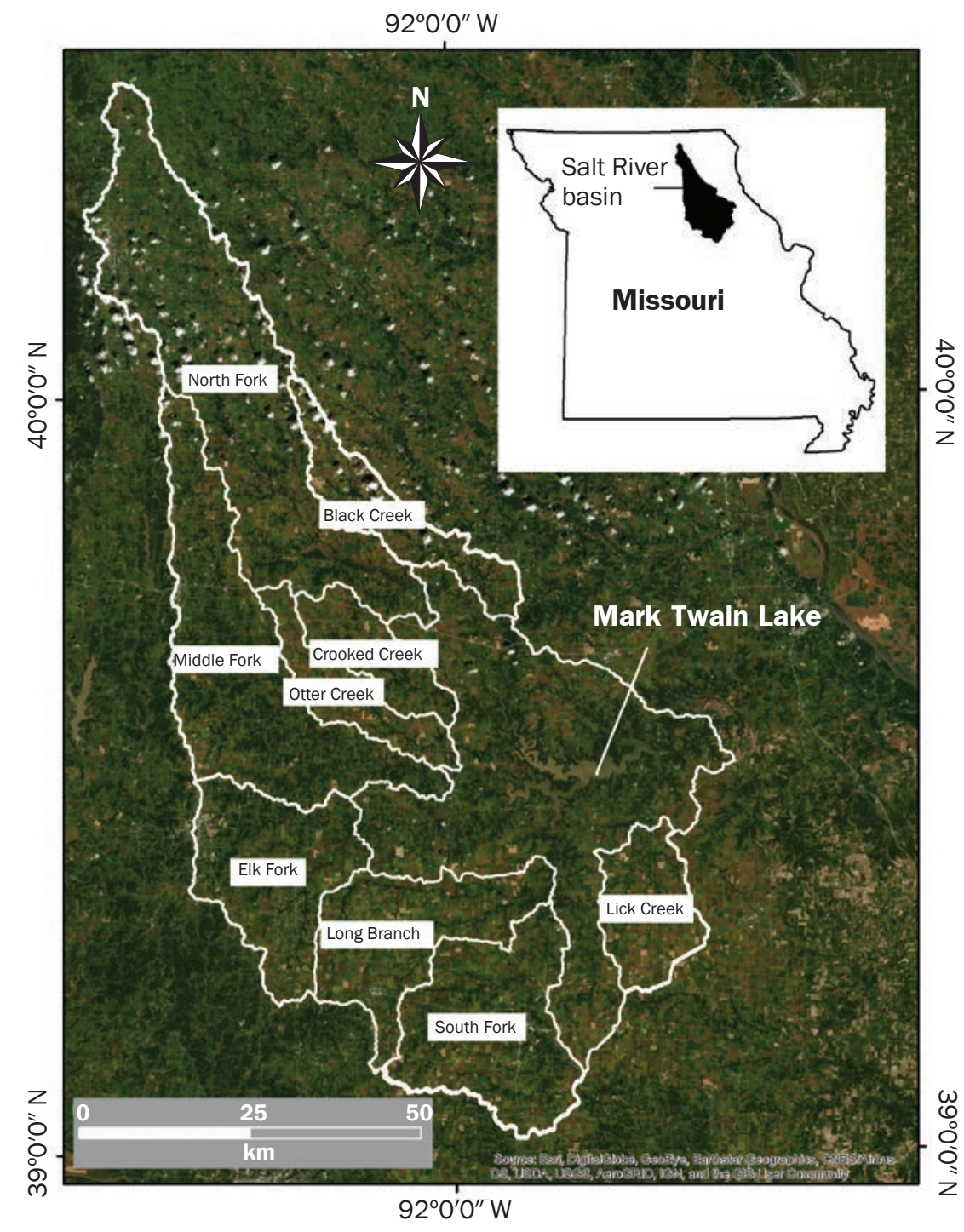

(Baffaut et al. 2015b). Land cover data layers for years 2006 to 2010 were downloaded from the Crop Data Layer (USDA NASS 2016). The various land use types in the land cover image layer were classified into six land cover categories (table 1).

For this analysis, cropland included the first three cover classes as shown in table 1. Four land cover definitions were defined to investigate the impact of different crops on annual constituent loads: all cropland combined, corn/sorghum and soybeans, corn/ sorghum only, and soybeans only.

Determination of the SVI. The SVI classification is based on the criteria for four risk classes derived using the combination of hydrologic soil group, slope, Universal Soil Loss Equation (USLE) soil erodibility was more powerful for SVI classification, especially in the presence of uniform hydrologic soil group and similar erodibility values throughout the watershed.

The SVI was calculated based on the hydrologic soil group when the soil is in an undrained condition, per SVI definition. There is very little drainage in MTL, so the effect of artificial drainage in SVI classification was not considered for this analysis. The $\mathrm{K}$-factor values were obtained from the surface layer $\mathrm{K}_{\mathrm{f}}$ values in the physical soil properties report downloaded from the WSS website. The $10 \mathrm{~m}$ DEM was obtained from the USGS website (Gesch et al. 2009). None of the soils in the watershed were classified as organic soils, per SVI definition, and none of the soils had significant amounts of rock fragments.

ArcGIS software (version 10.3; Esri, Redlands, California) was used to generate SVI maps for the study area. Model builder was used to create input files to calculate the SVI and generate SVI maps for runoff and leaching (figure 2). SSUR GO soil layers were used to generate raster layers for the hydrologic soil group, the $\mathrm{K}$-factor, and the presence of organic soils, which along with DEMgenerated slope, were used to generate layers for SVI vulnerability to runoff and leaching. SVI output layers represented the four SVI classes in numerical format set as follows: 1 for low, 2 for moderate, 3 for moderately high, and 4 for high. Area in the resultant layer was used to calculate fraction of watershed in each SVI risk class. The SVI is calculated for each year, based on where cropland used for row crops was located. The 2010 cropland data layer was used for mapping purposes.

Annual Constituent Loads. Flow and water quality monitoring data for sediment and nutrients have been collected at the USDA Agricultural Research Service (ARS) flow monitoring sites within the Central Mississippi River basin (CMRB) in the Long-Term Agricultural Research (LTAR) network (Baffaut et al. 2013, 2015a, 2015b; Lerch et al. 2008; Sadler et al. 2015). Those data are also available from the Sustaining the Earth's Watersheds, Agricultural Research Data System (STEWARDS, www.ars.usda. gov/watersheds/stewards) (Sadler et al. 2008; Steiner et al. 2008). Data considered for the SVI vulnerability to runoff were total and dissolved $\mathrm{N}$, total and dissolved P, and sediment annual loads estimated from stream flow data and constituent concentrations 
Table 3

Criteria for four classes of soil leaching potential (USDA NRCS 2016).

\begin{tabular}{|c|c|c|c|c|}
\hline \multirow{2}{*}{$\begin{array}{l}\text { Soil leaching } \\
\text { potential* } †\end{array}$} & \multicolumn{4}{|c|}{ Hydrologic soil group } \\
\hline & A & B & C & D \\
\hline Low & None & None & None & $\begin{array}{l}\text { All except } \\
\text { organic soils }\end{array}$ \\
\hline Moderate & None & $\begin{array}{l}\text { Slope } \neq \leq 12 \text { and } \\
\text { K-factor } \geq 0.24 \text { or } \\
\text { slope }>12\end{array}$ & $\begin{array}{l}\text { All except } \\
\text { organic soils }\end{array}$ & None \\
\hline Moderately high & Slope $>12$ & $\begin{array}{l}3 \leq \text { slope } \leq 12 \text { and } \\
\text { K-factor }<0.24\end{array}$ & None & None \\
\hline High & $\begin{array}{l}\text { Slope } \leq 12 \text { or } \\
\text { soils classified } \\
\text { organic soils }\end{array}$ & $\begin{array}{l}\text { Slope }<3 \text { and } \\
\text { K-factor }<0.24 \text { or } \\
\text { soils classified as } \\
\text { organic soils }\end{array}$ & $\begin{array}{l}\text { Soils classified as } \\
\text { organic soils }\end{array}$ & $\begin{array}{l}\text { Soils classified as } \\
\text { organic soils }\end{array}$ \\
\hline
\end{tabular}

*Coarse fragments (stones and rocks) in the soil make it easier for water to infiltrate rather than run off. If the coarse fragment content of the soil is greater than $30 \%$ by weight, the soil leaching potential is increased by two levels (moderate and moderately high increased to high, and low increased to moderately high). If the coarse fragment content is greater than $10 \%$ but less than $30 \%$, the soil leaching potential is increased one level.

†Artificial drainage of any type increases leaching potential by two classes (moderate and moderately high increases to high, and low increases to moderately high).

$\ddagger$ Slope measured as percentage.

\section{Figure 2}

Generation of Soil Vulnerability Index (SVI) layers.

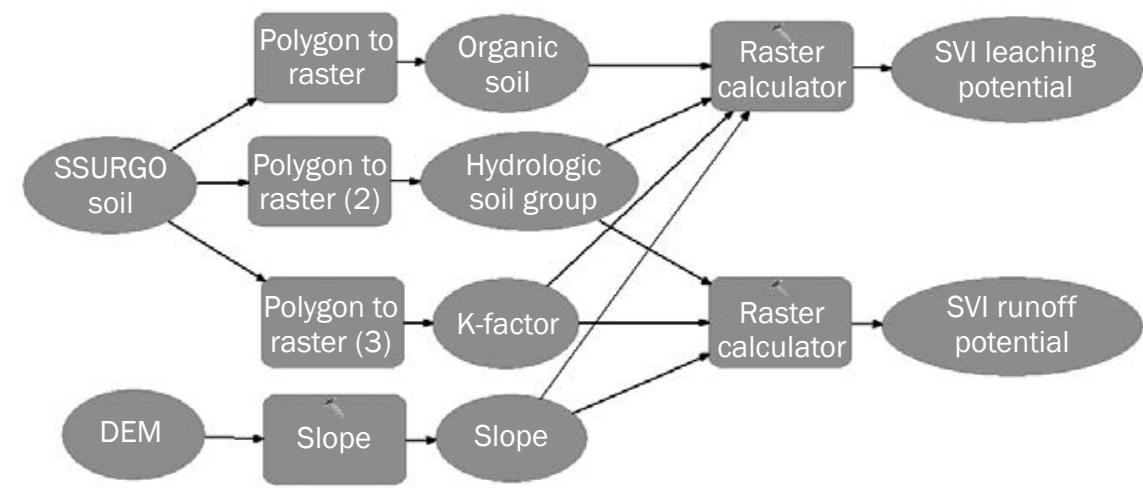

measured at the stream gauges on all the tributaries of the MTL watershed between the years 2006 to 2010 . Among the five constituent loads that were considered in this study, dissolved $\mathrm{N}$ was the only nutrient to follow the route via leaching. Hence, dissolved $\mathrm{N}$ was the only nutrient data considered for SVI vulnerability to leaching.

Many factors affect nutrient and sediment transport in streams (Sprague and Gronberg 2012). Annual sediment and nutrient loads are a function of precipitation across the watersheds as well as crop distribution and management of these crops (tillage and fertilization) throughout the watershed (Jha $\ln (L)=b_{0}+\sum_{i=1}^{n} b_{i} X_{i}$,

where $\ln (L)$ was the natural logarithm of annual constituent load, $b_{0}$ and $b$. were model coefficients, $X_{i}$ were the explanatory variables, and $n$ was the number of explanatory variables (Sprague and Gronberg 2012). Explanatory variables included rain factor $\left(X_{1}\right)$, crop factor $\left(X_{2}\right)$, and $X_{3}$ as the interactive term.

Rain factor incorporated the effect of rainfall amounts in the constituent loads, and crop factor included the effects of crop variety in the annual discharge. Rain factor included a normalized effect of various rainfall stations closest to each subwatershed in the area. Crop factor variable was calculated using the land cover fraction normalized with and without the incorporation of SVI vulnerability classes.

Rain Factor. Constituent loads are proportional to rainfall events (Tomer et al. 2010). Daily rainfall data for the 12 National Weather Service stations in MTL watershed region (figure 3) were recorded. Nearest rainfall station based on the nearest neighbor to the centroid of the watershed was assigned for each subwatershed.

Instead of using the total annual rainfall amount, a coefficient called "rain factor" was calculated as the ratio of annual rain to average annual rain for the five years under study (equation 2):

$$
\text { Rain Factor }=\frac{\text { Annual Rain }}{\text { Average Annual Rain }}
$$

The rain factor estimates dryness or wetness in a particular year as compared to average annual rainfall for that period. Also, the rainfall factor normalizes the effects of separate rainfall stations used for each subwatershed. The rain factor was calculated for each subwatershed for each year from 2006 to 2010.

Crop Factor. Effects of land use and land cover in nonpoint nutrient and sediment loads has been observed and confirmed worldwide over many decades (Beaulac and Reckhow 1982; Young et al. 1996; Smith et al. 2008; King et al. 2016). Variations in cropping systems and land use impact the average sediment and nutrient yield from a watershed. This variation in land use and land cover in a watershed was defined as the crop factor. Crop factor was formulated as a product of total cropland fraction in the watershed and the field level contaminant loads (equation 3) 


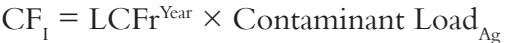

where $\mathrm{CF}_{\mathrm{I}}$ was the crop factor that related only to crop distribution, $\mathrm{LCFr}^{\text {Year }}$ was the total land cover fraction of the whole watershed in each year, and Contaminant Load $_{\mathrm{Ag}}$ was the average of the sediment and nutrient loads from hydrologic response units (HRUs) across the four SVI classes (Chan et al. 2017).

Modified Crop Factor Index. Our hypothesis was that the relationship between land use, precipitation, and nutrient or sediment loss is affected by the vulnerability of the land to runoff and leaching when used for crop production, and that this vulnerability can be identified with the SVI. Based on the assumption that land cover fraction in SVI high vulnerability class would contribute more in annual constituent loads as compared to the land cover fraction in SVI low risk class, the SVI spatial distribution was included in crop factor to develop the modified crop factor (equation 4):

$\mathrm{CF}_{\mathrm{SVI}}^{\mathrm{Year}}=\sum_{\mathrm{SVI}=1}^{4} \mathrm{LCFr}_{\mathrm{SVI}}^{\mathrm{Year}} \times$ Sediment $\operatorname{Load}_{\mathrm{SVI}}$

where $\mathrm{CF}_{\mathrm{SVI}}$ was the modified crop factor with weighted SVI spatial distribution, $\mathrm{LCFr}_{\mathrm{SVI}}^{\mathrm{Year}}$ was the land cover fraction of the whole watershed in each SVI class in each year, and Sediment Load $_{\text {SVI }}$ was the sediment load weighted based on each SVI risk class.

Estimates of constituent loads were based on SWAT model results for the Goodwater Creek Experimental Watershed (GCEW) (Chan et al. 2017). The GCEW $\left(72 \mathrm{~km}^{2}\right)$ is at the headwater in Long Branch watershed, itself a subwatershed in the Salt River basin. The SWAT model was calibrated based on stream loads at the outlet of GCEW, not with edge-of-field data. Because of this, there is uncertainty about the relative impact of field-scale and routing processes. However, the model was not calibrated for $\mathrm{N}$, and no uncertainty analysis was conducted. Land cover fraction in each SVI class for runoff potential was multiplied by the average contaminant loads from HRUs in each soil vulnerability class in the GCEW (table 4). A HRU is the smallest spatial unit of a model (Kalcic et al. 2015). For each HRU in the GCEW, land use was set to conventionally tilled corn followed by no-till soybean, and contaminant loads from the HRUs were determined using the SWAT model (Chan et al. 2017). The SVI for each HRU was calculated using the same criteria as in tables

\section{Figure 3}

Location map for rainfall stations in the Salt River basin.

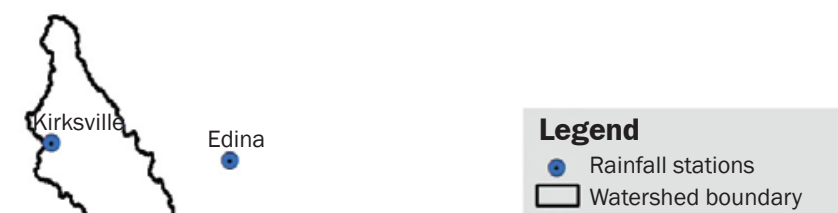

Watershed boundary
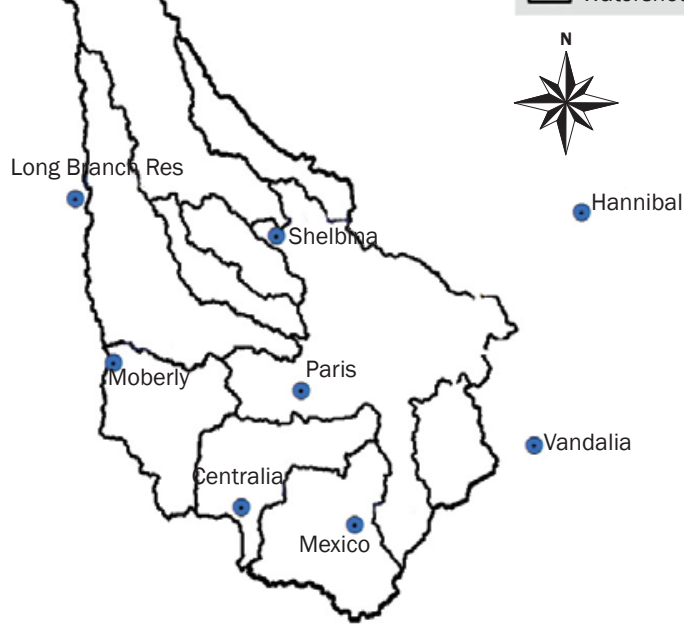

•

๑Columbia Regional Airport

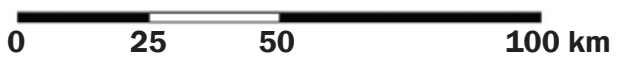

2 and 3. The SVI input parameters (slope, hydrologic soil group, and soil erodibility $\mathrm{K}$-factor) were determined from the model input data. The slope used was the HRU slope, which was calculated from the DEM in the ArcSWAT interface and the level of discretization used in the model. The hydrologic soil group and the K-factor for the soil inputs for each HRU were obtained from the SSURGO database. Since the Salt River contaminant loads for each SVI class of runoff potential were roughly twice the load of the class that is one level lower in the vulnerability category (Chan et al. 2017), similar proportion for contaminant loads (1,2, 4, and 8) was used for each class of the soil leaching potential. For $\mathrm{CF}_{\mathrm{I}}$, which was the crop factor value without including the SVI, an average of the four contaminant loads was used for both soil runoff and soil leaching.

Assessment of SVI Usefulness. Multiple regressions between annual loads of sediment and nutrients $(\mathrm{N}$ and $\mathrm{P})$ and different land cover definitions were performed in $\mathrm{R}$. Altogether 24 runs (20 for SVI runoff and 4 for SVI leaching) were performed using one of five output variables across varying spatial and temporal scales: five output variables of annual loads, four land cover definitions, all seven sites, and all five years combined (35 observations).

Similar analysis was performed using SVI classes for leaching against annual loads of dissolved N. Each regression was performed twice; once with crop factor and once with modified crop factor. Results were assessed according to their $p$-value and adjusted $r^{2}$ value. Results with $90 \%$ confidence interval (significance level of 0.1 ) were considered significant; results with $95 \%$ and $99 \%$ confidence intervals were also noted. When regression results were significant with both crop factor and modified crop factor, a greater significance (lower $p$-value) was considered an indication of a stronger relationship.

\section{Results and Discussion}

SVI Runoff and Leaching. Soils of the MTL watersheds were primarily in hydrologic soil group D, which was characterized by high runoff potential and low infiltration rate (figure 4a). Most of the subwatersheds consisted primarily of areas in the lower slope categories for runoff and leaching, except in North Fork and Middle Fork of the Salt River, which had slopes greater than $6 \%$ (figures $4 \mathrm{c}$ and $4 d$ ). Most of the soils had a soil erodibil- 
Table 4

Contaminant loads for Soil Vulnerability Index (SVI) classes (after Chan et al. 2017). $\mathrm{CF}_{\text {, }}$ is crop factor index; $\mathrm{CF}_{S \mathrm{SV}}$ is modifed crop factor index.

\begin{tabular}{|c|c|c|c|c|c|c|}
\hline sVI & Constituents & Crop factor & Low & Moderate & Moderately high & High \\
\hline \multirow[t]{8}{*}{ Soil runoff potential } & Total nitrogen & $\mathrm{CF}_{1}$ & 14.250 & & & \\
\hline & & $\mathrm{CF}_{\mathrm{SVI}}$ & 9.000 & 11.00 & 15.00 & 22.00 \\
\hline & & $\mathrm{CF}_{\mathrm{SVI}}$ & 0.700 & 1.10 & 1.70 & 2.90 \\
\hline & Sediment & $\mathrm{CF}_{1}$ & 2.300 & & & \\
\hline & & $\mathrm{CF}_{\mathrm{SVI}}$ & 0.700 & 1.20 & 2.20 & 5.10 \\
\hline & & $\mathrm{CF}_{\mathrm{SVI}}$ & 5.400 & 2.70 & 5.50 & 4.90 \\
\hline & Dissolved phosphorus & $\mathrm{CF}_{1}$ & 0.260 & & & \\
\hline & & $\mathrm{CF}_{\mathrm{SVI}}$ & 0.260 & 0.27 & 0.27 & 0.24 \\
\hline \multirow[t]{2}{*}{ Soil leaching potential } & Dissolved nitrogen & $\mathrm{CF}_{1}$ & 3.750 & & & \\
\hline & & $\mathrm{CF}_{\mathrm{sVI}}$ & 1.000 & 2.00 & 4.00 & 8.00 \\
\hline
\end{tabular}

\section{Figure 4}

Spatial distribution of Soil Vulnerability Index (SVI) main input parameters: (a) hydrologic soil group, (b) soil erodibility K-factor, (c) slope category for SVI runoff potential, (d) slope category for SVI leaching potential, and (e) land cover in 2010.

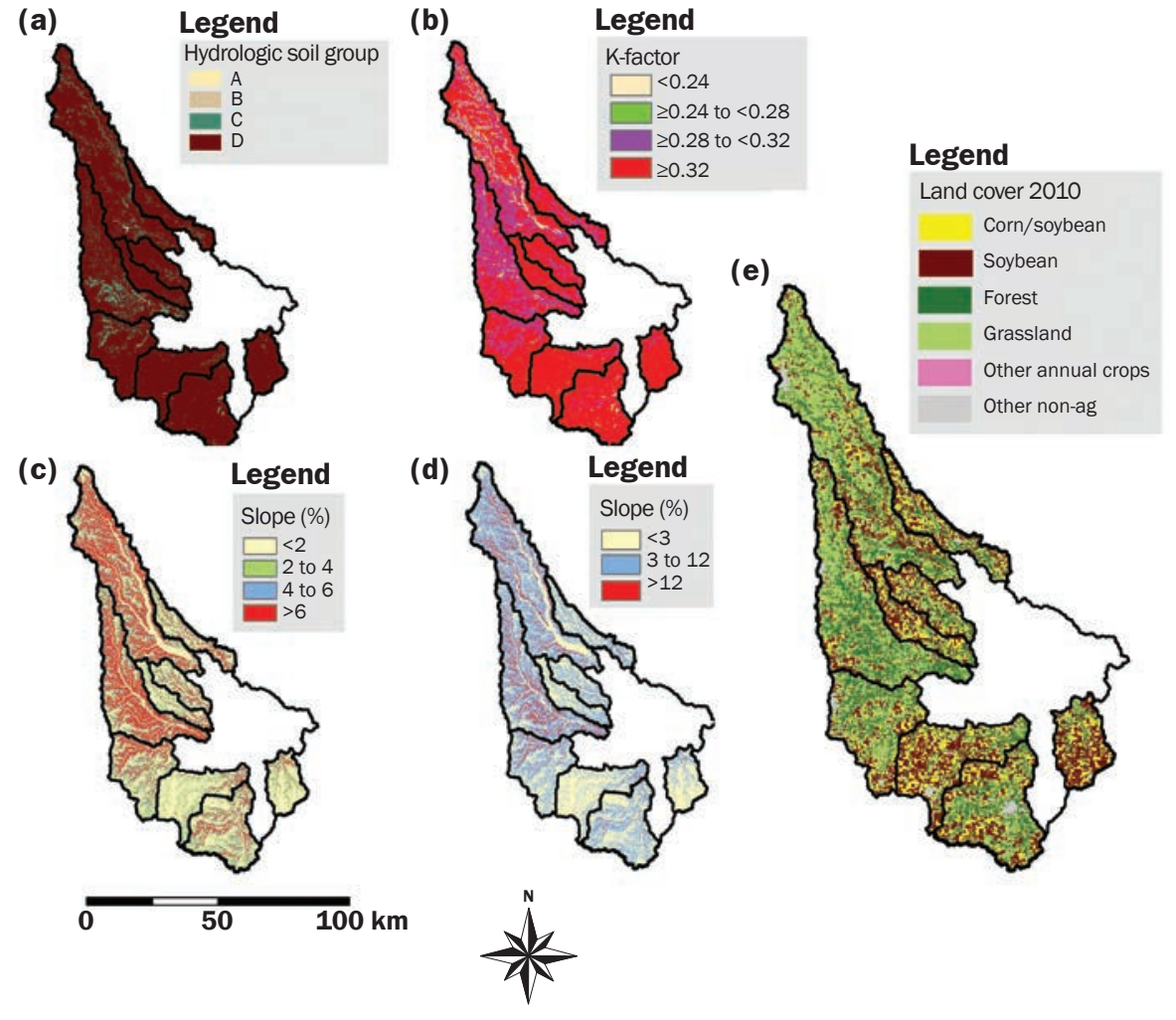

ity $\mathrm{K}$-factor value equal to or greater than 0.28 , which, per SVI definition, did not cause any variation in vulnerability class for runoff or leaching. Based on soil runoff potential, two subwatersheds (North Fork and Middle Fork) had dominant $(>50 \%)$ high vulnerability areas (figure 5, table 5). However, these high vulnerability areas were mostly in land other than cropland (usually grassland). The high risk and moderate risk were similarly distributed (both 36\%) in Elk Fork subwatershed. Moderate and moderately high classes for SVI runoff were dominant $(>40 \%)$ in cropland for all other subwatersheds (table
5). Low risk class for soil leaching potential was dominant (>90\% except $83 \%$ in Middle Fork) in the MTL watersheds (figure 6, table 6) because of the predominance of claypan soils, which have very slow permeability. The proportion of low vulnerability class for soil leaching potential increased when considering only cropland (table 6).

Impacts of Slope, Hydrologic Soil Group, and Erodibility K-factor on the SVI. The SVI runoff map and slope category maps for runoff potential were similar (figures $4 \mathrm{c}$ and 5), while maps of the hydrologic soil group and SVI vulnerability to leaching were identical (figures $4 \mathrm{a}$ and 6). Nearly $92 \%$ of soils in MTL watersheds and 99\% in the cropland were in hydrologic soil group D. The MTL watershed had uniformity in hydrologic soil group and soil erodibility K-factor, but there were a wide variety of slope categories throughout the watersheds. Due to fewer soils with soil erodibility K-factor less than 0.28 , less land was in the low vulnerability category for SVI runoff over the entire watershed (2\%) as well as for cropland (1\%). Land in the lowest slope category for runoff $(<2 \%)$ was classified as moderate vulnerability by the SVI. Land in the second lowest slope category for runoff ( $2 \%$ to $4 \%)$ was classified as moderately high, and land in the highest two slope categories for runoff ( $4 \%$ to $6 \%$ and $>4 \%$ ) was classified as high runoff risk by the SVI. Thus, the SVI runoff component was dominated by the effects of slope and $\mathrm{K}$-factor in this watershed, and the leaching component was totally dependent on the distribution of hydrologic soil groups irrespective of slope and soil erodibility K-factor (Lohani et al. 2020).

Assessment of the SVI versus Annual Constituent Loads. The annual constituent 


\section{Figure 5}

(a) Soil Vulnerability Index (SVI) runoff potential map and (b) runoff potential in 2010 croplands only in the Mark Twain Lake watershed. (a)

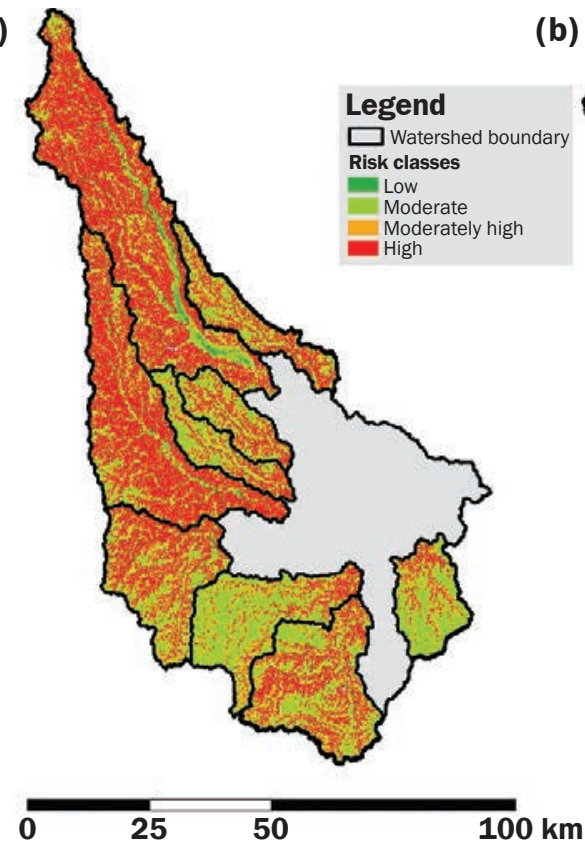

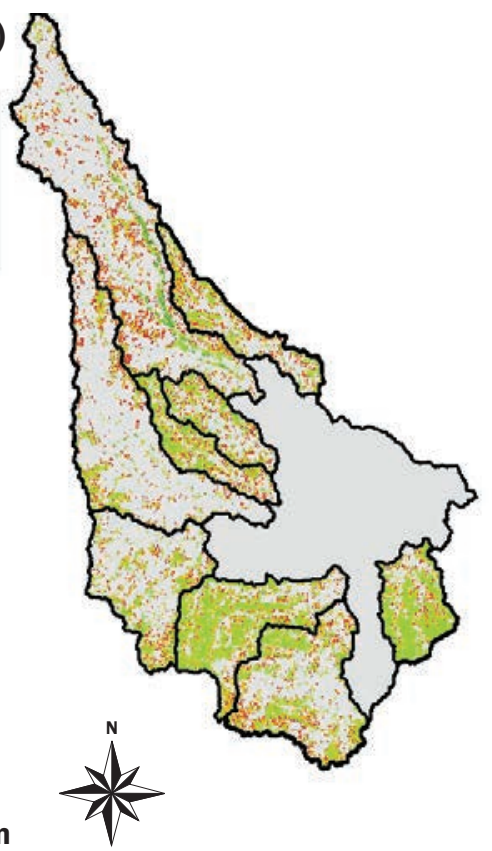

Table 5

Distribution of the Soil Vulnerability Index (SVI) runoff potential in the Mark Twain Lake watershed (values in parentheses are for cropland only, based on the 2010 National Land Cover Database).

\begin{tabular}{llllll}
\hline & & \multicolumn{3}{l}{ Area in each SVI class (\%) } \\
\cline { 3 - 6 } Site & Area $\left(\mathbf{k m}^{2}\right)$ & Low & Moderate & $\begin{array}{l}\text { Moderately } \\
\text { high }\end{array}$ & High \\
\hline North Fork & $1,188(291)$ & $4(7)$ & $23(43)$ & $20(23)$ & $53(27)$ \\
Middle Fork & $865(175)$ & $2(1)$ & $21(49)$ & $23(30)$ & $54(20)$ \\
Black Creek & $272(140)$ & $1(<1)$ & $43(58)$ & $26(26)$ & $30(16)$ \\
Crooked Creek & $212(105)$ & $<1(<1)$ & $47(64)$ & $25(22)$ & $28(13)$ \\
Otter Creek & $219(134)$ & $<1(<1)$ & $56(66)$ & $26(23)$ & $19(10)$ \\
Elk Fork & $510(157)$ & $1(<1)$ & $36(60)$ & $28(27)$ & $36(12)$ \\
Long Branch & $483(296)$ & $<1(<1)$ & $62(74)$ & $24(21)$ & $13(5)$ \\
South Fork & $598(262)$ & $<1(<1)$ & $44(63)$ & $28(26)$ & $28(11)$ \\
Lick Creek & $269(187)$ & $<1(<1)$ & $66(79)$ & $21(16)$ & $13(4)$ \\
& & & & &
\end{tabular}

loads per unit area were higher in 2008 to 2010 (figure 7) than in 2006 to 2007 , which was easily explained by the fact that 2006 and 2007 were drier than the other three years. Results from regression between crop factor index/modified crop factor index and constituent loads with different land cover definitions and SVI components showed no significant relationship except for dissolved $\mathrm{N}$ (table 7). The low $r^{2}$ values can be attributed to the fact that the regression investigated the impact of cropland only on the constituent loads; however, MTL subwatersheds with high proportions of high risk areas (North Fork, Middle Fork, Elk Fork, and Black Creek) were predominantly grasslands. Grasslands (including pastures), forests, and other noncroplands can also contribute to the annual constituent loads, which were not considered while performing regression against the SVI distribution. For each definition of cropland (all cropland combined, corn/sorghum and soybean, corn/sorghum only, and soybean only), the land cover factor was usually smaller when the SVI was considered. That was because a large proportion of cropland was in the low and moderate vulnerability classes, which have smaller area unit loss than the average loss used when the SVI was not considered. For dissolved P, the regression between annual losses and land cover factor was the same whether the SVI was considered or not. That was expected because the average unit area dissolved $\mathrm{P}$ loss was practically the same for all the vulnerability classes (table 4). In the MTL and GCEW watersheds, the vulnerability class depended in large part on slope, not on soil properties, which are similar throughout the watershed. On the other hand, dissolved $\mathrm{P}$ loss is affected by the volume of runoff (Easton et al. 2008), which is affected more by soil properties than by slope. Thus, adding the SVI to the crop factor did not have an effect on the $\mathrm{P}$ loss prediction.

The average rain factors across the seven subwatersheds for years 2006 to 2010 were $0.83,0.74,1.37,1.14$, and 0.96 . Regression results (tables 8,9 , and 10) showed that both for SVI runoff and leaching, the relationship with the modified crop factor was significant in more cases than with the crop factor. When combining all cropland, there was little change in the crop factor and modified crop factors, indicating that the distribution of the SVI among all cropland did not further help explain annual loads (tables 9 and 10). All cropland lumped together land that contributed to constituent loads (row crops) with land that contributed very little (hay and small grains like wheat or oats [Avena sativa $\mathrm{L}$.]). The sediment and nutrient loads were probably less sensitive to what was happening on land without row crops. However, by defining cropland as corn and soybean acres, which contributed heavily to constituent loads, the distribution of the runoff component of the SVI helped explain the loads (tables 8 and 9).

When the regression was performed for SVI runoff potential, and when cropland was defined as corn/sorghum and soybean acres, $\mathrm{CF}_{\text {SVI }}$ was more significant than $\mathrm{CF}_{\mathrm{I}}$ for all constituents except dissolved $\mathrm{P}$ (smaller $p$-value) (tables 8 and 9). Resulting adjusted $r^{2}$ was 0.55 for total $\mathrm{N}, 0.53$ for total $\mathrm{P}, 0.40$ for sediments, and 0.43 for dissolved $\mathrm{N}$ (table 8). Among those, there was an increase in significance level (90 to 95 significant) for 


\section{Figure 6}

(a) Soil Vulnerability Index (SVI) leaching potential map and (b) leaching potential in 2010 croplands only in the Mark Twain Lake watershed. (a)

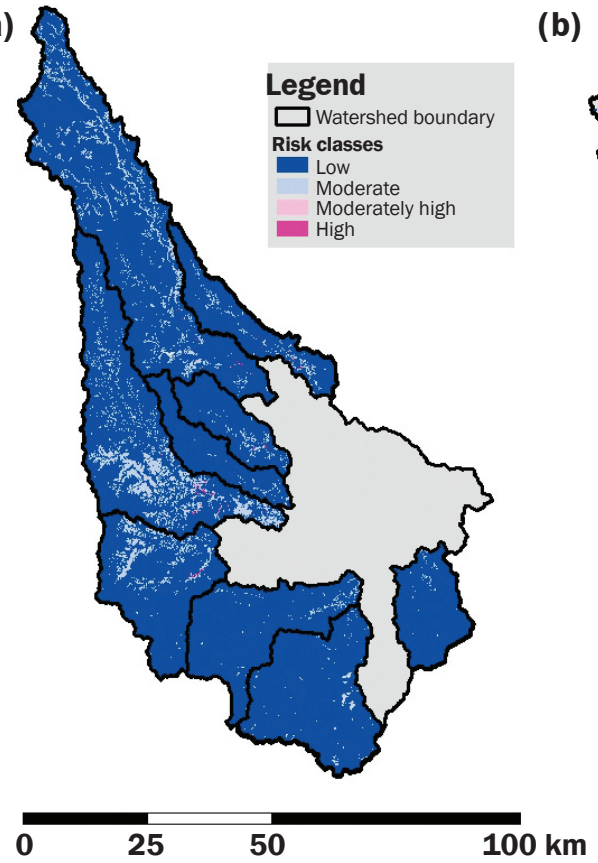

(b)

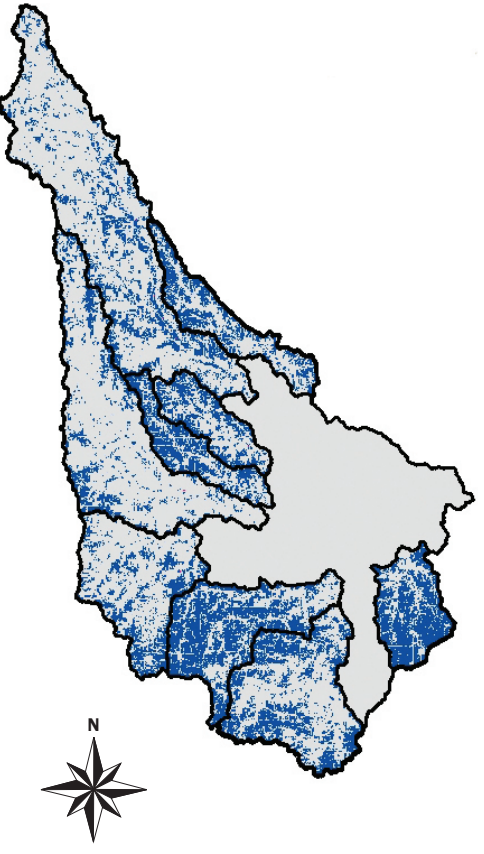

Table 6

Distribution of the Soil Vulnerability Index (SVI) leaching potential in the Mark Twain Lake watershed (values in parentheses are for cropland only, based on the 2010 National Land Cover Database).

\begin{tabular}{llllll}
\hline \multicolumn{5}{c}{ Area in SVI classes (\%) } \\
\cline { 3 - 6 } Site & Area $\left(\mathbf{k m}^{2}\right)$ & Low & Moderate & $\begin{array}{l}\text { Moderately } \\
\text { high }\end{array}$ & High \\
\hline North Fork & $1,188(291)$ & $91(96)$ & $9(4)$ & $<1(<1)$ & $<1(<1)$ \\
Middle Fork & $865(175)$ & $83(98)$ & $17(2)$ & $<1(<1)$ & $<1(<1)$ \\
Black Creek & $272(140)$ & $95(99)$ & $5(1)$ & $<1(<1)$ & $<1(<1)$ \\
Crooked Creek & $212(105)$ & $95(99)$ & $4(1)$ & $<1(0)$ & $<1(<1)$ \\
Otter Creek & $219(134)$ & $98(100)$ & $2(<1)$ & $<1(0)$ & $<1(0)$ \\
Elk Fork & $510(157)$ & $91(99)$ & $9(1)$ & $<1(<1)$ & $<1(<1)$ \\
Long Branch & $483(296)$ & $98(100)$ & $2(<1)$ & $<1(0)$ & $<1(0)$ \\
South Fork & $598(262)$ & $99(100)$ & $1(<1)$ & $<1(0)$ & $<1(0)$ \\
Lick Creek & $269(187)$ & $99(100)$ & $1(<1)$ & $<1(0)$ & $<1(0)$ \\
& & & & &
\end{tabular}

sediment. The crop factor and modified crop factor produced similar results for dissolved $\mathrm{P}$, as discussed previously. When cropland was defined by land with corn or sorghum only, $\mathrm{CF}_{\text {SVI }}$ was more significant than $\mathrm{CF}_{\mathrm{I}}$ for total $\mathrm{N}$ and sediments (tables 8 and 9). When cropland was defined only by soybean acres, the relationship using the modified crop factor was more significant than using the crop factor in defining sediments (adjusted $r^{2}$ was 0.38 ) and dissolved P (adjusted $r^{2}$ was 0.57 ) losses from both soybean and corn/sorghum fields (King et al. 2016; Smith et al. 2008).

For the SVI leaching potential, regression using the modified crop factor was significant in more cases than with the crop factor when land cover definition included a combination of corn/sorghum and soybean (tables 8 and 10). The modified crop factor slightly improved the significance of the regression for cropland defined as land in corn/sorghum and soybean (adjusted $r^{2}$ was 0.41 with modified crop factor and 0.40 with crop factor), or as land in soybean only (adjusted $r^{2}$ was 0.422 with modified crop factor and 0.420 with crop factor; tables 8 and 10). Regression results for the leaching component of the SVI showed that there was a significant relationship between dissolved $\mathrm{NO}_{3}$ loads and croplands defined as land in soybean only or combined with other crops. This significant relationship supports the argument that management activities like timing, fertilizers, and specific rotation in a soybean crop rotation can alter $\mathrm{NO}_{3}$ export from a watershed and thus modify water quality (Jones et al. 2016). Soybeans, being legumes, are able to absorb the atmospheric $\mathrm{N}$, and thus do not require added $\mathrm{N}$ fertilizer. Thus, excess $\mathrm{N}$ would not be expected from soybeans unless fertilizer had been applied. However, Jones et al. (2016) suggest that soybean acres in the Raccoon River watershed in Iowa play an important role in the transport of $\mathrm{NO}_{3}$ loads because of such processes as mineralization of soil organic $\mathrm{N}$ in leachable $\mathrm{NO}_{3}$.

\section{Summary and Conclusions}

In this study, the SVI was used to identify inherently vulnerable areas in the MTL watershed in central Missouri. The MTL watershed includes 10 subwatersheds, all characterized by claypan soils. The high risk areas for SVI runoff potential were areas with greater slope.The SVI leaching class was predominantly low throughout the watershed, irrespective of the slope. The 2010 land use layer depicted that fraction of high risk areas were less when considering only cropland. Most of the high risk areas in the MTL watersheds were grasslands.

Multiple regression analysis was performed between annual constituent loads of sediment and nutrients ( $\mathrm{N}$ and $\mathrm{P}$ ), precipitation, and land cover distributions. Varying weights were given to varying risk classes, as identified by the SVI, to investigate a possible relationship between constituent loadings 


\section{Figure 7}

Annual constituent loads per unit area in the Mark Twain Lake watershed.

(a)

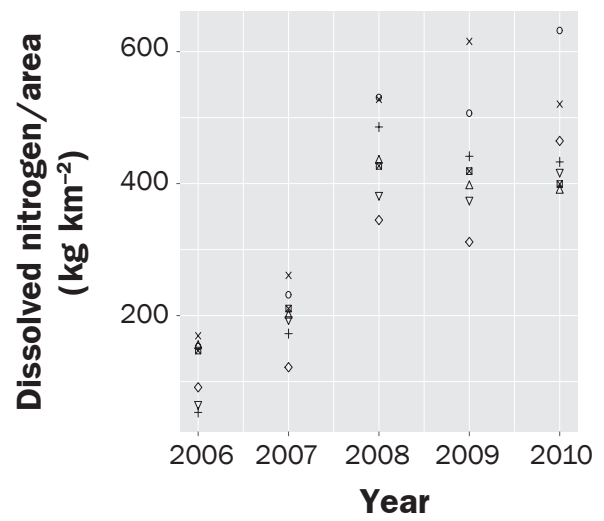

(d)

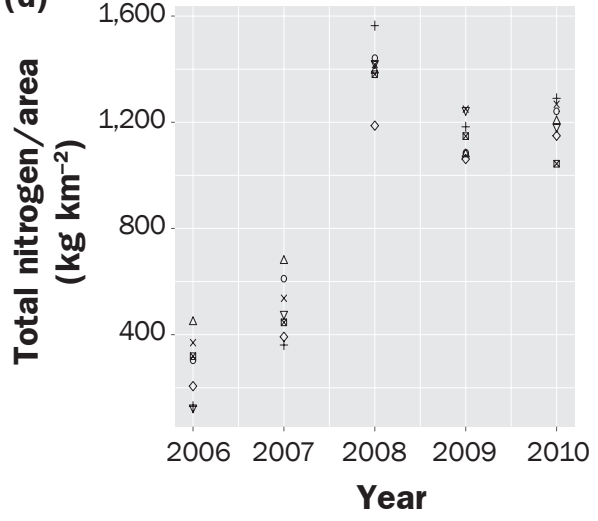

(b)

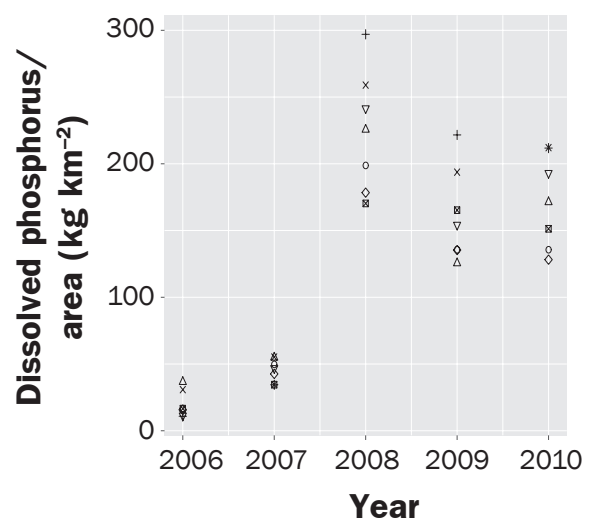

(e)

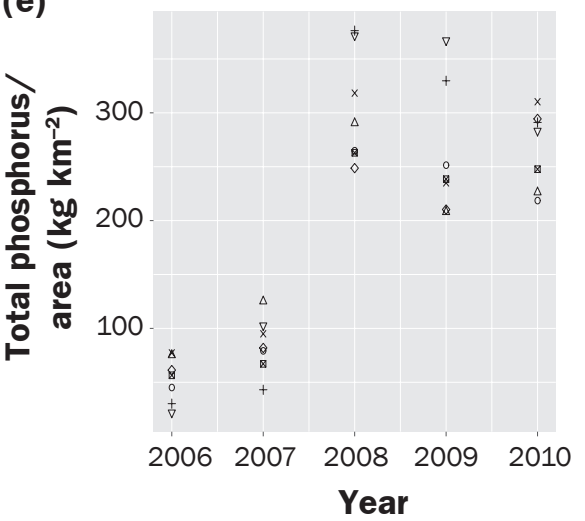

(c)

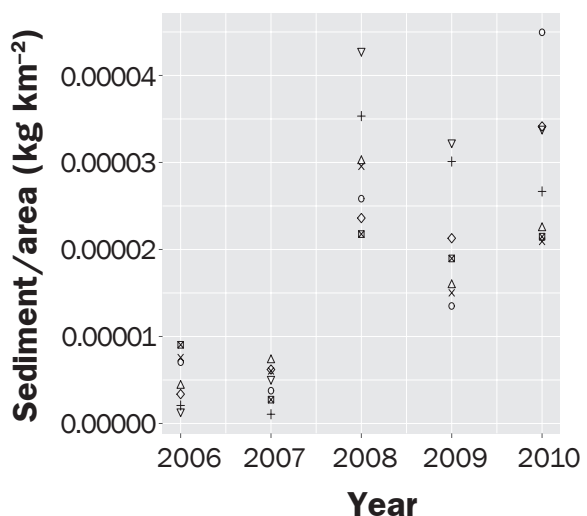

Legend

Site

- Crooked Creek

$\triangle$ Elk Fork

+ Lick Creek

$\times$ Long Branch

$\diamond$ Middle Fork

$\nabla$ North Fork

$\otimes$ South Fork and fraction of the watershed in each SVI class. The modified crop factor index, which was the crop factor with weighted SVI spatial distribution, helped explain constituent and sediment loads in the MTL watersheds. There were many instances where the relationships using the crop factor were more significant than by using the modified crop factor. However, there were more instances when the SVI weighted crop factor explained constituent loads better than the crop factor with cropland distribution only. Incorporating the SVI runoff component into the crop factor improved the relationship between constituent load and cropland distribution when cropland was defined as corn sorghum only or combined with other row crops (here, soybean). For the leaching component, the relationship was improved by using the SVI when the crops defining cropland included soybean (soybean only or combined with corn/sorghum). This suggests that $\mathrm{NO}_{3}$ loss by subsurface flow was associated to extraneous $\mathrm{N}$ fertilizer applied

Table 7

Relationship showing $r^{2}$ values between crop factor index (CF)/modified crop factor index $\left(\mathrm{CF}_{\mathrm{SV}}\right)$ and constituent loads* with different land cover definitions and Soil Vulnerability Index (SVI) components.

\begin{tabular}{|c|c|c|c|c|c|c|}
\hline \multirow[b]{2}{*}{ Crop factor $\dagger$} & \multicolumn{5}{|c|}{ SVI runoff } & \multirow{2}{*}{$\begin{array}{l}\text { SVI } \\
\text { leaching } \\
\text { DNITR }\end{array}$} \\
\hline & TNITR & TPHOS & SEDT & DNITR & DPHOS & \\
\hline $\mathrm{CF}_{\mathrm{SVI} \text {-allag }}$ & 0.000 & 0.000 & 0.001 & 0.046 & 0.016 & 0.042 \\
\hline $\mathrm{CF}_{\text {|_allag }}$ & 0.001 & 0.000 & 0.003 & 0.043 & 0.015 & 0.043 \\
\hline $\mathrm{CF}_{\mathrm{SVI}} \mathrm{COSSB}$ & 0.031 & 0.025 & 0.018 & 0.150 & 0.058 & 0.137 \\
\hline $\mathrm{CF}_{1-} \mathrm{COSSB}$ & 0.030 & 0.021 & 0.004 & 0.134 & 0.058 & 0.134 \\
\hline $\mathrm{CF}_{\mathrm{SVI}} \mathrm{COS}$ & 0.001 & 0.000 & 0.007 & 0.063 & 0.011 & 0.053 \\
\hline $\mathrm{CF}_{1-} \mathrm{COS}$ & 0.001 & 0.000 & 0.012 & 0.052 & 0.011 & 0.052 \\
\hline $\mathrm{CF}_{\mathrm{SVl}} \_\mathrm{SB}$ & 0.062 & 0.057 & 0.059 & 0.186 & 0.094 & 0.180 \\
\hline $\mathrm{CF}_{1-} \mathrm{SB}$ & 0.061 & 0.052 & 0.027 & 0.178 & 0.093 & 0.177 \\
\hline
\end{tabular}

*Constituent loads: TNITR = total nitrogen. TPHOS = total phosphorus. SEDT = sediments. DNITR $=$ dissolved nitrogen. DPHOS $=$ dissolved phosphorus.

†Land crop definitions: allag = all cropland combined. COSSB = corn/sorghum + soybean . $\mathrm{COS}=$ corn/sorghum only. SB = soybean only.

to the soybean fields either separately or combined with other crops.

The study showed a moderate correlation between the SVI and annual pollution loads of the claypan MTL subwatersheds. It should be noted that the data included were for seven sites and five years. Analysis of additional nonclaypan sites is highly recommended to ensure 
Table 8

Linear regression model results for Soil Vulnerability Index (SVI) runoff and leaching.

\begin{tabular}{|c|c|c|c|c|c|c|c|c|}
\hline \multirow[b]{2}{*}{ SVI } & \multirow[b]{2}{*}{$\begin{array}{l}\text { Constituents } \\
\text { load } \dagger\end{array}$} & \multirow[b]{2}{*}{$\begin{array}{l}\text { Land cover } \\
\text { combination }\end{array}$} & \multicolumn{3}{|c|}{ Modified crop factor } & \multicolumn{3}{|l|}{ Crop factor } \\
\hline & & & $\begin{array}{l}\text { Significance } \\
\text { level (\%) }\end{array}$ & $\operatorname{Pr}(>|t|)$ & $\begin{array}{l}\text { Adjusted } \\
R^{2}\end{array}$ & $\begin{array}{l}\text { Significance } \\
\text { level (\%) }\end{array}$ & $\operatorname{Pr}(>|t|)$ & $\begin{array}{l}\text { Adjusted } \\
R^{2}\end{array}$ \\
\hline \multirow[t]{11}{*}{ SVI runoff } & \multirow[t]{3}{*}{ TNITR } & $\begin{array}{l}\text { Corn/sorghum } \\
\text { + soybean }\end{array}$ & $95 * *$ & 0.014 & 0.55 & $95 * *$ & 0.021 & 0.54 \\
\hline & & $\begin{array}{l}\text { Corn/sorghum } \\
\text { only }\end{array}$ & $90 *$ & 0.062 & 0.51 & $90 *$ & 0.096 & 0.50 \\
\hline & & Soybean only & $95 * *$ & 0.016 & 0.55 & $95 * *$ & 0.014 & 0.55 \\
\hline & TPHOS & $\begin{array}{l}\text { Corn/sorghum } \\
+ \text { soybean }\end{array}$ & 90 & 0.096 & 0.53 & - & - & - \\
\hline & \multirow[t]{3}{*}{ SEDT } & $\begin{array}{l}\text { Corn/sorghum } \\
+ \text { soybean }\end{array}$ & $95 * *$ & 0.014 & 0.40 & $90 *$ & 0.082 & 0.34 \\
\hline & & $\begin{array}{l}\text { Corn/sorghum } \\
\text { only }\end{array}$ & $90 *$ & 0.076 & 0.35 & - & - & - \\
\hline & & Soybean only & $95 * *$ & 0.030 & 0.38 & $95 * *$ & 0.044 & 0.36 \\
\hline & \multirow[t]{2}{*}{ DNITR } & $\begin{array}{l}\text { Corn/sorghum } \\
\text { + soybean }\end{array}$ & $95 * *$ & 0.027 & 0.43 & $95 * *$ & 0.046 & 0.40 \\
\hline & & Soybean only & $95 * *$ & 0.034 & 0.43 & $95 * *$ & 0.032 & 0.42 \\
\hline & \multirow[t]{2}{*}{ DPHOS } & $\begin{array}{l}\text { Corn/sorghum } \\
+ \text { soybean }\end{array}$ & $90 *$ & 0.070 & 0.57 & $90 *$ & 0.067 & 0.57 \\
\hline & & Soybean only & $90 *$ & 0.080 & 0.57 & $90 *$ & 0.081 & 0.57 \\
\hline \multirow[t]{2}{*}{ SVI leaching } & \multirow[t]{2}{*}{ DNITR } & $\begin{array}{l}\text { Corn/sorghum } \\
+ \text { soybean }\end{array}$ & $95 * *$ & 0.040 & 0.41 & $95 * *$ & 0.046 & 0.40 \\
\hline & & Soybean only & $95 * *$ & 0.032 & 0.422 & $95 * *$ & 0.032 & 0.42 \\
\hline
\end{tabular}

*, ** indicate significance of $p$-value as 0.01 and 0.05 , respectively.

†Constituent loads: TNITR = total nitrogen. TPHOS $=$ total phosphorus. SEDT $=$ sediments. DNITR $=$ dissolved nitrogen. DPHOS $=$ dissolved phosphorus.

relationship of the SVI and annual constituent loads in different soil types.

\section{Acknowledgements}

We gratefully acknowledge the USDA Natural Resources Conservation Service (NRCS) Conservation Effects Assessment Project (CEAP) for providing funding for this research, and both USDA Agricultural Research Service and USDA NRCS CEAP for mutually funding the data collection.

\section{References}

Arnold, J.G., R. Srinivasan, R.S. Muttiah, and J.R. Williams. 1998. Large area hydrologic modeling and assessment, Part I: Model development. Journal of American Water Resources Association 34(1):73-89.

Baffaut, C., F. Ghidey, K.A. Sudduth, R.N. Lerch, and E.J. Sadler. 2013. Long-term suspended sediment transport in the Goodwater Creek Experimental Watershed and Salt River basin, Missouri, USA. Water Resources Research 49:7827-7830.

Baffaut, C., E.J. Sadler, and F. Ghidey. 2015a. Long-term agroecosystem research in the Central Mississippi River Basin: Goodwater Creek Experimental Watershed flow data. Journal of Environmental Quality 44:18-27.

Baffaut, C., E.J. Sadler, F. Ghidey, and S.H. Anderson. 2015b. Long-term agroecosystem research in the Central Mississippi River Basin: SWAT simulation of flow and water quality in the Goodwater Creek Experimental Watershed. Journal of Environmental Quality 44:84-96.
Beaulac, M.N., and K.H. Reckhow. 1982. An Examination of Land use: Nutrient Export Relationships. JAWRA Journal of the American Water Resources Association 18:1013-1024. Birr,A.S., and D.J. Mulla. 2001. Evaluation of the phosphorus index in watersheds at the regional scale. Journal of Environmental Quality 30:2018-2025.

Bosch, D., F. Theurer, R. Bingner, G. Felton, and I. Chaubey. 1998. Evaluation of the AnnAGNPS Water Quality Model. In Agricultural Non-Point Source Water Quality Models: Their Use and Application, eds. E.P. John, L.T Daniel, and L.H. Rodney, 45-54. Boca Raton, FL: USDA Cooperative State Research, Education, and Extension Services and Environmental \& Water Resources Institute. Butler, D.M., D.H. Franklin, M.L. Cabrera, L.M. Risse, D.E. Radcliffe, L.T. West, and J.W. Gaskin. 2010. Assessment of the Georgia Phosphorus Index on farm at the field scale for grassland management. Journal of Soil and Water Conservation 65(3):200-210, doi:10.2489/jswc.65.3.200.

Chan, R., C. Baffaut, A.L. Thompson, and E.J. Sadler. 2017 Validating the Soil Vulnerability Index for a claypan watershed. Catena 148:185-194.

Easton, Z.M., D.R. Fuka, M.T. Walter, D.M. Cowan, E.M. Schneiderman, and T.S. Steenhuis. 2008 Re-conceptualizing the soil and water assessment tool (SWAT) model to predict runoff from variable source areas. Journal of Hydrology 348(3-4):279-291.

Eghball, B., and J.E. Gilley. 2001. Phosphorus risk assessment index evaluation using runoff measurements. Journal of Soil and Water Conservation 56(3):202-206.
Gesch, D., G. Evans, J. Mauck, J. Hutchinson, and W.J. Carswell Jr. 2009. The National Map-Elevation: US Geological Survey Fact Sheet 2009-3053. Reston, VA: US Geological Survey.

Harmel, R.D., H.A.Torbert, P.B. DeLaune, B.E. Haggard, and R.L. Haney. 2005. Field evaluation of three phosphorus indices on new application sites in Texas. Journal of Soil and Water Conservation 60(1):29-42.

Jha, M.K., K.E. Schilling, P.W. Gassman, and C.F. Wolter. 2010. Targeting land-use change for nitrate-nitrogen load reductions in an agricultural watershed. Journal of Soil and Water Conservation 65(6):342-352, doi:10.2489/jswc.65.6.342

Jones, C.S., A. Seeman, P.M. Kyveryga, K.E.Schilling, A Kiel, K.S. Chan, and C.F. Wolter. 2016. Crop rotation and Raccoon River nitrate. Journal of Soil and Water Conservation 71(3):206-219, doi:10.2489/ jswc.71.3.206.

Kalcic, M.M, I. Chaubey, and J. Frankenberger. 2015 Defining soil and water assessment tool (SWAT) hydrologic response units (HRUs) by field boundaries. International Journal of Agriculture and Biological Engineering 8(3):69-80.

King, K.W., M.R. Williams, and N.R. Fausey. 2016. Effect of crop type and season on nutrient leaching to tile drainage under a corn-soybean rotation. Journal of Soil and Water Conservation 71(1):56-68, doi:10.2489/jswc.71.1.56.

Lee, S., A.M. Sadeghi, G.W. McCarty, C. Baffaut, S. Lohani, L.F. Duriancik, A.Thompson, I.Yeo, and C.Wallace. 2018. 
Table 9

Regression results for soil runoff per land cover combinations.

\begin{tabular}{|c|c|c|c|c|c|}
\hline \multirow[b]{2}{*}{ SVI runoff } & \multicolumn{2}{|c|}{$\mathrm{CF}_{\text {sVI }}$ more significant than $\mathbf{C F}_{1}$} & \multirow[b]{2}{*}{$\begin{array}{l}\mathrm{CF}_{1} \text { more significant } \\
\text { than } \mathrm{CF}_{\mathrm{svl}} \text { (\# variables) }\end{array}$} & \multirow[b]{2}{*}{$\begin{array}{l}\text { Both } \mathrm{CF}_{\mathrm{svl}} \text { and } \mathrm{CF}_{1} \\
\text { were insignificant } \\
\text { (\# variables) }\end{array}$} & \multirow[b]{2}{*}{$\begin{array}{l}\text { Total variables } \\
\text { constituent loads } \dagger\end{array}$} \\
\hline & $\begin{array}{l}\text { Only } \mathrm{CF}_{\text {svl }} \text { significant } \\
\text { (\# variables) }\end{array}$ & $\begin{array}{l}\mathrm{CF}_{\text {sv! improved }} \\
\text { significance } \\
\text { (\# variables) } \\
\end{array}$ & & & \\
\hline All cropland combined & 0 & 0 & 0 & 100 & 5 \\
\hline $\begin{array}{l}\text { Corn/sorghum } \\
+ \text { soybean }\end{array}$ & 1:TPHOS & $\begin{array}{l}\text { 3:TNITR, SEDT, } \\
\text { DNITR (1: SEDT)* }\end{array}$ & 1:DPHOS & 0 & 5 \\
\hline Soybean only & 0 & 2: SEDT, DPHOS & 2:TNITR, DNITR & 1:TPHOS & 5 \\
\hline
\end{tabular}

*Value in parentheses refers to cases where the significance level was improved by using the Soil Vulnerability Index (SVI).

†Constituent loads: TNITR $=$ total nitrogen. TPHOS $=$ total phosphorus. SEDT $=$ sediments. DNITR $=$ dissolved nitrogen. DPHOS $=$ dissolved phosphorus.

Table 10

Regression results for soil leaching per land cover combinations.

\begin{tabular}{|c|c|c|c|c|}
\hline \multirow[b]{2}{*}{$\begin{array}{l}\text { Soil Vulnerability } \\
\text { Index leaching }\end{array}$} & \multicolumn{2}{|c|}{$\mathrm{CF}_{\mathrm{sV} I}$ more significant than $\mathrm{CF}_{\mathrm{I}}$} & \multirow[b]{2}{*}{$\begin{array}{l}\mathbf{C F}_{1} \text { more } \\
\text { significant } \\
\text { than } \mathbf{C F}_{\mathrm{sVI}}\end{array}$} & \multirow[b]{2}{*}{$\begin{array}{l}\text { Both } \mathbf{C F}_{\text {svl }} \text { and } \mathrm{CF}_{\text {, }} \\
\text { were insignificant }\end{array}$} \\
\hline & $\begin{array}{l}\text { Only } \mathbf{C F}_{\text {svI }} \\
\text { significant }\end{array}$ & $\begin{array}{l}\mathrm{CF}_{\text {sVV }} \text { improved } \\
\text { significance }\end{array}$ & & \\
\hline $\begin{array}{l}\text { All cropland } \\
\text { combined }\end{array}$ & No & No & No & Yes \\
\hline $\begin{array}{l}\text { Corn/sorghum } \\
+ \text { soybeans }\end{array}$ & No & Yes & No & No \\
\hline $\begin{array}{l}\text { Corn/sorghum } \\
\text { only }\end{array}$ & No & No & No & Yes \\
\hline Soybeans only & No & Yes & No & No \\
\hline
\end{tabular}

Assessing the suitability of the Soil Vulnerability Index (SVI) on identifying cropland vulnerable to nitrogen loadings using the SWAT model. Catena 167:1-12.

Lerch, R.N., E.J. Sadler, N.R. Kitchen, K.A. Sudduth, R.J Kremer, D.B. Myers, C. Baffaut, S.H. Anderson, and C.H. Lin. 2008. Overview of the Mark Twain Lake/Salt River basin Conservation Effects Assessment Project. Journal of Soil and Water Conservation 63(6):345-359, doi:10.2489/jswc.63.6.345.

Lohani, S., C. Baffaut,A.L.Thompson, N.Aryal, R.L. Bingner, D.L. Bjorneberg, D.D. Bosch, R.B. Bryant, A. Buda, S.M. Dabney, A.R. Davis, L.F. Duriancik, D.E. James, K.W. King, P.J.A. Kleinman, M. Locke, G.W. McCarty, L.A. Pease, M.L. Reba, D.R. Smith, M.D. Tomer, T.L. Veith, M.R. Williams, and L.M.W. Yasarer. 2020. Performance of the Soil Vulnerability Index with respect to slope, digital elevation model resolution, and hydrologic soil group. Journal Soil and Water Conservation 75(1):12-27, doi:10.2489/jswc.75.1.12.

Sadler, E.J., R.N. Lerch, N.R. Kitchen, S.H. Anderson, C. Baffaut, K.A. Sudduth, A.A. Prato, R.J. Kremer, E.D. Vories, D.B. Myers, R. Broz, R.J. Miles, and F.J. Young. 2015. Long-term agroecosystem research in the Central Mississippi River Basin: Introduction, establishment, and overview. Journal of Environmental Quality 44:3-12.

Sadler, E.J., J.L. Steiner, J-S. Chen, G. Wilson, J. Ross, T. Oster, D.E. James, B. Vandenberg, K. Cole, and J.L. Hatfield. 2008. Sustaining the Earth's Watersheds-
Agricultural Research Data System: User perspective, operation, and application. Journal of Soil and Water Conservation 63(6):577-589, doi:10.2489/ jswc.63.6.577.

Schilling, K.E., T.M. Isenhart, J.A. Palmer, C.F. Wolter, and J. Spooner. 2011. Impacts of land-cover change on suspended sediment transport in two agricultural watersheds. Journal of the American Water Resources Association (JAWRA) 47(4):672-686, doi: 10.1111/j.1752-1688.2011.00533.

Smith, D.R., S.J. Livingston, B.W. Zuercher, M. Larose, G.C. Heathman, and C. Huang. 2008. Nutrient losses from row crop agriculture in Indiana. Journal of Soil and Water Conservation 63(6):396-409, doi:10.2489/ jswc.63.6.396

Soil Survey Staff. 2015. Web Soil Survey. https:// websoilsurvey.sc.egov.usda.gov/. Wasington, DC: USDA Natural Resources Conservation Service.

Sprague, L.A., and J.A.M. Gronberg. 2012. Relating management practices and nutrient export in agricultural watersheds of the United States. Journal of Environmental Quality 41(6):1939-1950.

Steiner, J.L., E.J. Sadler, J-S. Chen, G. Wilson, D.E. James, B. Vandenberg, J. Ross, T. Oster, and K.J. Cole. 2008. Sustaining the Earth's Watersheds-Agricultural Research Data System: Overview of development and challenges. Journal of Soil and Water Conservation 63(6):569-576, doi:10.2489/jswc.63.6.569.
Thompson, A.L., C. Baffaut, S. Lohani, L.F. Duriancik, M.L. Norfleet, and K. Ingram. 2020. Purpose, development, and synthesis of the SoilVulnerability Index for inherent vulnerability classification of cropland soils. Journal of Soil and Water Conservation 75(1):1-11, doi:10.2489/ jswc.75.1.1.

Tomer, M.D., C.G.Wilson, T.B. Moorman, K.J. Cole, D. Herr, and T.M. Isenhart. 2010. Source-pathway separation of multiple contaminants during a rainfall-runoff event in an artificially drained agricultural watershed. Journal of Environmental Quality 39:882-895.

USDA NASS (National Agricultural Statistics Service). 2016. Cropland Data Layer. Washington, DC: National Agricultural Statistics Service. https://nassgeodata.gmu. edu/CropScape/.

USDA NRCS (Natural Resources Conservation Service). 2012.Assessment of the Effects of Conservation Practices on Cultivated Cropland in the Upper Mississippi River Basin, 189. Conservation Effects Assessment Project (CEAP) report. Washington, DC: USDA Natural Resources Conservation Service.

USDA NRCS. 2016. Effects of Conservation Practice Adoption on Cultivated Cropland Acres in Western Lake Erie Basin, 2003-06 and 2012. Conservation Effects Assessment Project (CEAP) special study report. Washington, DC: USDA Natural Resources Conservation Service.

Veith, T.L., A.N. Sharpley, J.L. Weld, and W.J. Gburek. 2005. Comparison of measured and simulated phosphorus losses with indexed site vulnerability. Transactions of the ASAE 48(2):557-565.

Yasarer, L.M.W., S. Lohani, R.L. Bingner, M.A. Locke, C. Baffaut, and A.L. Thompson. 2020. Assessment of the Soil Vulnerability Index and comparison with AnnGNPS in two Lower Mississippi River Basin watersheds. Journal of Soil and Water Conservation 75(1):53-61, doi:10.2489/jswc.75.1.53.

Young, W.J., F.M. Marston, and J.R. Davis. 1996. Nutrient exports and land use in Australian catchments. Journal of Environmental Management 47:165-183. 